\title{
HUBUNGAN PERAN KEPALA RUANGAN DENGAN SELF-EFFICACY PERAWAT DALAM PENCEGAHAN PASIEN JATUH
}

\author{
I Gusti Ngurah Bagus Yogi Saputra*, Ni Putu Emy Darma Yanti, Ni Kadek Ayu Suarningsih \\ Programa Studi Sarjana Keperawatan Dan Profesi Ners Fakultas Kedokteran Universitas Udayana \\ *Email: yogi.saputra68@gmail.com
}

\begin{abstract}
ABSTRAK
Peran kepemimpinan kepala ruangan memiliki fungsi penting yang dapat berpengaruh pada selfefficacy perawat, self-efficacy merupakan kemampuan perawat dalam pelaksanaan tugas khususnya patient safety sehingga dapat menghasilkan layanan keperawatan yang berkualitas. Penelitian ini bertujuan mengidentifikasi hubungan peran kepala ruangan dengan self-efficacy perawat dalam pencegahan pasien jatuh. Desain yang digunakan dalam penelitian ini adalah analitik korelatif cross-sectional dengan jumlah sampel sebanyak 81 orang dari 101 populasi perawat pelaksana yang dipilih menggunakan teknik simple random sampling. Kuesioner yang digunakan yaitu kuesioner Peran Kepala Ruangan dan Scales For Assessing Self-Efficacy Of Nurse For Preventing Falls. Hasil penelitian ini menunjukan bahwa terdapat hubungan yang signifikan dengan arah korelasi positif dan kekuatan hubungan sedang antara peran kepala ruangan dengan self-efficacy perawat pelaksana ( $p$-value $<0,001, \mathrm{r}=0,554)$. Hubungan korelasi positif artinya jika peran kepala ruangan baik maka, nilai self-efficacy perawat pelaksana dalam melakukan pencegahan pasien jatuh juga akan baik, begitu sebaliknya. Penelitian ini dilakukan untuk kepala ruangan agar dapat memotivasi perawat pelaksana guna meningkatkan self-efficacy perawat dalam mencegah pasien jatuh sehingga dapat meningkatkan kualitas mutu pelayanan keperawatan.
\end{abstract}

Kata kunci: Peran kepala ruangan, pencegahan pasien jatuh, self-efficacy perawat

\section{THE RELATIONSHIP OF THE HEAD OF NURSE' ROLES WTH NURSE' SELF. EFFICACY IN PREVENTING PATIENTS FROM FALLS}

\begin{abstract}
The head nurse' leadership roles had an important function that could influence the nurses' selfefficacy; self-efficacy is the ability of nurses in carrying out specific task, especially patient safety in purposed producing good nursing actions. Thisa study aims to identify the relationship of the head of nurse' roles with nurse' self-efficacy in preventing patients from falls. This study aused a cross-sectionaloi correlative analytic designs with total sample consists of 81 people from 101 associate nurse population selected by simple random sampling technique. The questionnaire used was the role of head of nurses' questionnaire and Scales for Assessing Self-Efficacy of Nurses for Preventing Falls. The results of this study indicated that there is a significanty relationshipo with positive correlation direction and moderate relationship strength between the role of the head nurse and the nurses' self-efficacy. (p-value $=0.001, r=0.554$ ). The positive relationship correlation means that if the role of the head of the nurse is good, then the value of the associate nurse's self-efficacy in preventing patients from falls will also be good, and vice versa. This research conducted for the head of the nurses in order to motivate associate nurses to improve nurses' self-efficacy in preventing patients from falls in purposed they could improve the quality of nursing services.
\end{abstract}

Keywords: Associate nurse's self-efficacy, head of nurse roles, patients fall prevention

\section{PENDAHULUAN}

Keselamatan pasien menjadi salah satu komponen penting untuk mempertahankan mutu dan meningkatkan usaha pelayanan di rumah sakit. (McFadden, Stock, \&- Gowen,
2015). Akan tetapi, hingga kini masih ditemukan beberapa insiden patient safety, salah satunya adalah pasien jatuh. Berdasarkan data prevalensi dari The Commission Sentinel Event, tahun (2009) 
didapatkan 465 laporan pasien jatuh dengan luka di Rumah Sakit Amerika Serikat terdapat $30-50 \%$ jatuh dengan menghasilkan luka (Joint Committe International, (2013). KKPRS (2010) menyatakan insiden KTD edi Indonesia mencapai $46,67 \%$ dengan data kejadian di Bali sebesar $6,67 \%$. Hal ini membuktikan bahwa insiden pasien jatuh di Indonesia masih tinggi dan masih jauh dari standar.

Insiden jatuh dapat menghasilkan dampak yang merugikan untuk pasien. Penelitian Isomi Miake-Lye et al (2013), mengatakan jatuh dapat merugikan bagi pasien, salah satu dampaknya adalah cidera fisik. Pasien jatuh juga meningkatkan kerugian finansial bagi rumah sakit hingga mencapai \$30 miliyar tahun 2012 (CDC, 2014). Perawat berperan penting dalam ikut melakukan pencegahan pasien jatuh sebagai bagian dalam pengembangan program keselamatan pasien (Cahyono, 2015). Berkaitan dengan hal tersebut perawat harus memiliki keyakinan diri self-efficacy dalam melaksanakan tugasnya untuk mencegah pasien jatuh di rumah sakit. Perawat dituntut untuk selalu memberikan pelayanan yang baik. Hal tersebut dapat dicapai jika perawat memiliki self-efficacy yang tinggi. Hasil studi mengenai pentingnya self-efficacy terhadap perawat sebelumnya dilakukan dan mendapatkan adanya peningkatan signifikan terhadap kinerja perawat (Indrawati, 2014; Lee \& Ko, 2010).

Beberapa upaya dapat dilakukan dalam meningkatkan self-efficacy perawat. Selfefficacy dapat bersumber dari peningkatan kekuatan keyakinan melalui orang lain (persuasi verbal). Kepala ruang perawatan dapat memberikan peningkatan self-efficacy perawat melalui adanya persuasi verbal di rumah sakit. Peran kepemimpinan kepala ruangan di bagi menjadi tiga yaitu peran interpersonal, peran informational, dan decisional (Gillies, 1994). Penelitian yang dilakukan sebelumnya terdapat perbedaan persentase dari tiga peran kepala ruangan. Penelitian Chanifah (2013), mendapatkan hasil dari 43 respondenn bahwa peran yang paling berpengaruh adalah peran decisional dengan persentase $69,8 \%$ dibandingan dengan peran interpersonal 55,8\% dan peran informational 46,5\%.

Berdasarkan hasil studi pendahuluann pada unit rawat inap Rumah Sakit pemerintah di Bali. Diperoleh terdapat $50 \%$ perawat menyatakan belum menerima laporan verbal mengenai risiko jatuh pada pasien yang dikelola. Selain itu, $87,5 \%$ perawat belum merasa yakin sepenuhnya saat ditanya mengenai pencegahan pasien dari terjatuh jika dikaitkan dengan keterlibatkan keluarga atau pengunjung untuk sama - sama memperhatikan program pencegahan jatuh pada pasien. $62,5 \%$ perawat juga mengatakan masih ragu untuk memberi tahu perawat lain tentang tindakan berikutnya apa yang harus dilakukan untuk mencegah pasien jatuh.

\section{METODE}

Penelitian ini merupakan penelitian kuantitatif dengan analitik korelatif dan menggunakan desain penelitian crosssectional. Analisis bivariat dilakukan menggunakan uji non-parametrik yaitu rankspearman karena data tidak terdistribusi normal. Populasi yang digunakan dalam penelitian ini adalah seluruh perawat di ruang rawat inap X di Rumah Sakit pemerintah di Bali yang berjumlah 101 orang. Berdasarkan perhitungan rumus Slovin, didapatkan total sampel pada penelitian ini berjumlah 81 orang yang telah sesuai dengan kriteria inklusi dan ekslusi serta terpilih acak dengan teknik simple random sampling menggunakan lotre.

Instrumen kuesioner data karakteristik individu (jenis kelamin, usia, tingkat pendidikan, dan pengalaman bekerja), kuesioner Scales For Assessing Self-Efficacy of Nurses For Preventing Falls, dan kuesioner Peran Kepala Ruangan digunakan dalam penelitian ini dan telah dinyatakan valid dan reliabel. Pengumpulan data dilakukan pada tanggal 11 hingga 18 April 2019 di Rumah Sakit pemerintah di Bali. Data dikumpulkan oleh peneliti dengan dibantu oleh dua orang Enumerator yaitu Mahasiswa Keperawatan Universitas Udayana yang sebelumnya sudah mengetahui cara pengisian kuesioner dan kriteria inklusi $\&$ eksklusi. Setelah mendapat ijin pengambilan data, peneliti melakukan pengambilan data pada jam istirahat setiap 
shift pagi dan sore perawat di ruangan rawat inapi Rumah Sakita pemerintah di Bali. Peneliti bertemu dengan masing - masing kepala ruangan di setiap ruangan terlebih dahulu untuk meminta ijin mengambil data kuesioner pada perawat. Peneliti membagikan kuesioner lalu pengisian ketiga kuesioner secara sekaligus dalam waktu 20 menit. Selanjutnya peneliti melakukan pengecekan pada kuesioner untuk memastikan kelengkapan data. Prosedur ini dilakukan setiap harinya untuk memenuhi jumlah sampel $(n=81)$.Penelitian ini telah mendapatkan kelayakan etik berdasarkan hasil telaah yang telah dilakukan oleh Komisi Etik Fakultas Kedokteran Universitas Udayana dengan Keterangan Kelayakan Etik Nomor 1800/UN14.2.2. VII. 14/LP/2019.

\section{HASIL}

Distribusi karakteristik responden disajikan padai tabel 1.

Tabel 1.

Karakteristik responden $(\mathrm{n}=81)$

\begin{tabular}{ccc}
\hline Karakteristik & $\mathrm{f}$ & $\%$ \\
\hline Jenis Kelamin & & \\
Laki-laki & 7 & 8,6 \\
Perempuan & 74 & 91,4 \\
\hline Tingkat Pendidikan & & \\
S1 & 21 & 25,9 \\
D3 & 60 & 74,1 \\
\hline
\end{tabular}

Penelitian ini mendapatkan hasil gambaran peran kepala ruangan pada tabel 2 dan selfefficacy perawat disajikan pada tabel 3.

Tabel 2.

Gambaran peran kepala ruangan $(\mathrm{n}=81)$

\begin{tabular}{lcccc}
\hline & Median & min & Maks & IQR \\
\hline Peran Kepala Ruangan & 89,00 & 74 & 117 & 13 \\
\hline Peran Interpersonal & 31,00 & 25 & 48 & 5 \\
Peran Informasional & 29,00 & 24 & 35 & 4 \\
Peran Decisional & 29,00 & 20 & 38 & 6 \\
\hline
\end{tabular}

Tabel 3.

Gambaran self-efficacy perawat $(\mathrm{n}=81)$

\begin{tabular}{lccc}
\hline & Median & Min & Maks \\
Self-efficacy perawat dalam pencegahan pasien jatuh & 54,00 & 30 & 66 \\
\hline Mastery Experiences (Pengalaman Keberhasilan) & 14,00 & 7 & 18 \\
Vicarious Experiences (Pengalaman Orang Lain) & 9,00 & 3 & 12 \\
Verbal Persuasion (Persuasi Verbal) & 15,00 & 5 & 18 \\
Physiological and Affective States (Keadaan Fisiologis dan Emosional) & 16,00 & 9 & 18 \\
\hline
\end{tabular}

Penelitian ini mendapatkan hasil bahwa peran kepala ruangan dengan self-efficacy terdapat hubungan yang signifikan antara perawat dijabarkan pada tabel 4.

Tabel 4.

Hubungan peran kepala ruangan dengan self-efficacy perawat

\begin{tabular}{|c|c|c|}
\hline \multicolumn{3}{|l|}{ Uji Korelasi Rank Spearman } \\
\hline Variabel & $p$-value & $\mathrm{r}$ \\
\hline $\begin{array}{l}\text { Self Efficacy Perawat Pelaksana dalam pencegahan pasien Jatuh } \\
\text { Peran Kepala Ruangan }\end{array}$ & $<0,001^{*}$ & 0,554 \\
\hline
\end{tabular}


* Bermakna pada $a=0,05$

\section{PEMBAHASAN}

\section{Gambaran peran kepala ruangan}

Hasil penelitian menunjukkan bahwa berdasarkan nilai maksimal yang ditemukan, diketahui bahwa perawat pelaksana mempersepsikan kepala ruangan telah menjalankan peran yang optimal sebagai kepala ruangan. Kepala ruang merupakan tenaga perawat profesional yang memiliki wewenang dan tanggung jawab dalam dalam mengelola kegiatan pelayanan keperawatan pada satu ruang perawatan (Marquis \& Huston, 2014). Kepala ruangan memegang peran penting dalam memotivasi staf untuk mencapai atujuan organisasi (Nursalam, 2014) dan memiliki kemampuan untuk melakukan beberapa fungsi manajerial seperti fungsi pengawasan, informasi dan sebagainya yang bertujuan untuk mengefektifkan dan memberikan efisiensi sumber daya guna mencapai tujuan yang telah ditetapkan (Hadrianti, Yassir, \& Kadir, 2012).

Katz (1995) menyatakani bahwa pemimpin ruangan perlu memiliki tiga pendekatan keterampilan yang dapat berguna untuk berjalannya proses manajemen. Keterampilan teknis memberikan adanya pemahaman, dan kecakapan dalam jenis kegiatan tertentu, khususnya yang melibatkan metode, proses, prosedur, atau teknik. Keterampilan teknis melibatkan pengetahuan khusus, kemampuan analitis dalam spesialisasi itu, dan fasilitas dalam penggunaan alat dan teknik disiplin khusus (Katz, 1955). Pada poin kedua, keterampilan manusia menyiratkan kemampuan untuk bekerja secara efektif sebagai anggota kelompok dan untuk membangun upaya kerja sama dalam tim yang sedang dipimpin. Keterampilan manusia terutama berkaitan dengan bekerja dengan orang-orang (Katz,11955). Sedangkan pada poin ketiga, keahlian konseptual melibatkan kemampuan untuk melihat perusahaan secara keseluruhan termasuk mengenali bagaimana berbagai fungsi organisasi saling bergantung satu sama lain, dan bagaimana perubahan pada bagian mana pun memengaruhi yang lain; dan meluas ke memvisualisasikan hubungan bisnis individu dengan industri, masyarakat, dan politik, kekuatan sosial, dan ekonomi bangsa secara keseluruhan (Katz, 1955). Kepala ruangan juga diartikan sebagai pelaksana terdepan pelayanan kesehatan di rumah sakit yang diwajibkan memiliki keterampilan untuk melakukan fungsi kepala ruangan. Kepala ruangan yang memiliki pendidikan yang tinggi memiliki kosakatah yang luas, sehingga kepala ruangan dapat memengaruhi perawat pelaksana untuk mencapai visi ruangan dengan menggunakan teknik komunikasi efektif (Nursalam, 2011).

\section{Gambaran self-efficacy perawat dalam pencegahan pasien jatuh}

Hasil penelitian ini menunjukan bahwa nilai terendah yang dimiliki perawat dapat diartikan sebagai minimnya keyakinan diri perawat pelaksana dalam melaksanakan pencegahan pasien jatuh ketika bekerja di Rumah Sakit pemerintah di Bali, begitu pula sebaliknya. Temuan dalam penelitian ini juga menemukan bahwa ditemukan nilai median yang dapat diartikan bahwa self-efficacy perawat pelaksana dalam melakukan pencegahan pasien jatuh cenderung mendekati nilai yang optimal. Kondisi tersebut memungkinkan perawat untuk memberikan kinerja yang terbaik dalam melakukan pencegahan pasien jatuh dikarenakan perawat pelaksana memiliki keyakinan yang tinggi dalam melakukan tugas keperawatan tersebut. Hal ini sesuai dengan teori Bandura (2008) yang menyatakan bahwa ketika individu memiliki keyakinan yang tinggi terhadap tugas spesifik, maka hal tersebut dapat membangkitkan kinerja atau performa yang optimal.

Penelitian mengenai Self-efficacy perawat pada pelaksanaan pencegahan pasien jatuh hingga kini masih minim dilakukan. Akan tetapi, hasil penelitian ini serupa dengan penelitian mengenai self-efficacy perawat pelaksana berkaitan dengan pelaksanaan tugas keperawatan telah dilakukan sebelumnya. Triana, Yanti, dan Sulistiowati (2017) melalui penelitiannya di instalasi rawat inap rumah sakit menemukan bahwa nilai self-efficacy perawat memiliki varian yang berbeda - beda tergantung beberapa faktor yang memengaruhi perawat pelaksana itu sendiri. 
Perawat dituntut untuk selalu memberikan performa baik dan hal tersebut dapat dicapai jika perawat memiliki self-efficacy yang tinggi. Performa yang baik akan mengoptimalkan penyelenggaraan asuhan keperawatan sehingga kualitas layanan keperawatan akan meningkati (Nursalam, 2011). Hasil studi mengenai pentingnya selfefficacy terhadap perawat sebelumnya dilakukan dan mendapatkan adanya peningkatan signifikan terhadap kinerja perawat (Indrawati, 2014; Lee \& Ko, 2010).

Terdapat beberapa faktor yang dapat memengaruhi self-efficacy perawat dalam melakukan pekerjaan keperawatan khususnya dalam melakukan pencegahan pasien jatuh. Bandura dalam Alwilsol, 2004) menyatakan bahwa Pengalaman Keberhasilan (Mastery Exsperiences) yang sering didapatkan akan meningkatkan self-efficacy yang dimiliki seseorang sedangkan kegagalan akan menurunkan self-efficacy dirinya. Ketika keberhasilan yang adidapat seseorang lebih banyak karena faktor-faktor di luar dirinya, biasanya tidak akan membawa pengaruh terhadap peningkatan self-efficacy. Sebaliknya, jika keberhasilan tersebut didapatkan dengan melalui hambatan yang besar dan merupakan hasil perjuangan sendiri, maka hal itu akan membawa pengaruh pada peningkatan self-efficacy. Begitu pula dengan adanya pengalaman melakukan pencegahan pasien jatuh yang sebelumnya pernah dilakukan oleh perawat pelaksana menjadikan perawat pelaksana secara mantap dapat yakin dalam melakukan pencegahan pasien jatuh ketika bekerja.

Persuasi Sosial (Social Persuation) memainkan peranan yang siginfikan dalam meningkatkan self-efficacy perawat pelaksana. Informasi tentang kemampuan yang disampaikan secara verbal oleh seseorang yang berpengaruh biasanya digunakan untuk meyakinkan seseorang bahwa dirinya cukup mampu melakukan suatu tugas. Selama penelitian, penelitian melihat kepala ruangan sangat antusias untuk meyakinkan perawat dan memberikan motivasi untuk selalu memberikan kinerja terbaiki khususnya untuk meminimalisir terjadinya pasien jatuh selama perawatan. Hal tersebut dapat menjadi sebuah persuasi yang dapat meningkatkan self-efficacy perawat dalam mencegah pasien terjatuh.

Adanya perawat pelaksana yang memiliki nilai tertinggi self-efficacy pada penelitian ini dapat bersumber dari adanya peningkatan kekuatan keyakinan melalui orang lain (persuasi verbal). Individu yang diberikan informasi secarai lisan atau individu mendapat bujukan maupun sugesti untuk percaya bahwa dapat mengatasi masalah yang akan muncul cenderung memiliki penguasaan tinggi terhadap berbagai tugas yang diberikan (Bandura, 2008). Persuasi secara verbal juga merupakan hal yang sering digunakan dalam mengubah sikap dan perilaku individu. Hal ini didasarkan pada dorongan pihak luar mengenai pengarahan perilaku individu sesuai dengan tujuan yang ingin dicapai. Peningkatan keyakinan tersebut dapat menjadi sumber munculnya self-efficacy yang tinggi pada individu (Saam \& Wahyuni, 2013).

\section{Hubungan peran kepala ruangan dengan self-efficacy perawat dalam pencegahan pasien jatuh}

Hasil penelitian yang dilaksanakan di Rumah Sakit pemerintah di Bali diperoleh bahwa ada hubungan antara peran kepala ruangan dengan self-efficacy perawat dengan arah hubungan positifi dengan kekuatan korelasi sedang. Arah hubungan positif menunjukan bahwa jika peran kepala ruangan baik maka self-efficacy perawat pelaksana khususnya dalam pencegahan pasien jatuh juga meningkat begitu juga sebaliknya.

Kepala ruangan memegang peran penting dalama memotivasi staf untuk mencapai tujuan organisasi (Nursalam, 2014). Peran interpersonal kepala ruangan yaitu dukungan dan motivasi dari kepala ruangan merupakan bagian dari persuasif sosial yang memengaruhi self-efficacy perawat sehingga upaya pencegahan jatuh dapat dilakukan secara maksimal. Hal ini dikarenakan adanya peningkatan keyakinan diri oleh adanya peningkatan motivasi dalam diri individu.

Penelitian mengenai peran kepala ruangan terhadap self-efficacy perawat dalam mencegah pasien jatuh hingga kini masih minim dilakukan. Akan tetapi, penelitian sebelumnya dapat dikaitkan jika dianalisis 
dari sumber-sumber self-efficacy. Jeezaa et al. (2015) menyatakan bahwa self-efficacy dapat meningkatkan optimisme dan komitmen perawat untuk melakukan tindakan keperawatan. Hal yang sama diungkapkan oleh Wallin et al. (2012) yang menyatakan bahwa ketika individu memiliki self-efficacy yang baik, kecenderungan untuk melakukan keberhasilan dalam bekerja adalah sangat tinggi.

Peran interpersonal kepala ruang menuntut agar proaktif terhadap segala hal yang berhubungan dengan pelaksanaan keselamatan pasien, sehingga perilaku yang ditampilkan perawat pelaksana baik (Arnold, \& Boggs, 2015; Mom, Fourné, \& Jansen, 2015). Warshawsky, Havens, dans Knafl (2012) menyatakan bahwa pemimpin yang bertindak secara proaktif terhadap permasalahan yang ada memiliki kontribusi pengaruh yang sangat besar terhadap pencegahan perilaku yang tidak baik atau pencegahan kesalahan dalam melaksanakan keselamatan pasien. Saat seorang memimpin ruang perawatan, peran interpersonal seperti motivasi dan support kepada bawahan perlu untuk diberikan guna menjamin hasil kerja unit organisasi yang dipimpin (Thoha, 2015).

Peran informasi informational terbagi atas peran kepala ruang sebagai sumber informasi, diseminator, dan juru bicara (Robbins \& Judge, 2015). Warshawsky et al, (2012) menyatakan bahwa kemampuan peran informational kepala ruang sangat dibutuhkan untuk secara proaktif memantau dan mencegah efek yang buruk dari pelayanan keselamatan pasien yang tidak sesuai standar operasional prosedur oleh perawat pelaksana.

Penelitian Leverenz dan Lape (2018) menyatakan bahwa edukasi yang diberikan oleh kepala ruangan kepada staf keperawatan memberikan peningkatan yang signifikan pada skill perawat dalam melakukan pencegahan jatuh pada pasien yang berada pada perawatan jangka panjang. Selain itu jika dianalisis lebih mendalam, kemampuan kepala ruangan dalam memberikan edukasi kepada staf perawat mencerminkan adanya peran informasional kepalaa ruangan sehingga meningkatkan kinerja perawat (Bastable, 2017).

Peran pengambil keputusan decisional terbagi atas peran kepala ruang sebagai enterpreuner, peredam gangguan, pembagi sumber daya dan dan, perunding untuk organisasia (Miri et al., 20152; Robbins, 2015). McKanzie, Winkelen, dan Grewal (2011) yang menyatakan bahwa kepala ruang sebagai manajer dituntut untuk memiliki kemampuan yang baik dalam mengambilan keputusan yang dapat meningkatkan kemampuan organisasi untuk melaksanakan evaluasi kegiatan yang telah terlaksana dan dapat melaksanakan penyusunan perencanaan organisasi yang lebih terstruktur.

Penelitian Yettia dan Novieastari (2018) juga menyatakan bahwa terdapat hubungan yang signifikan dari peran kepala ruangan terhadap perilaku perawat pelaksana dalam melaksanakan program keselamatan pasien termasuk dalam pencegahan sasaran pasien jatuh. Penelitian tersebut, mendapatkan bahwa kepala ruangan dapat memberikan keputusan keputusan (peran decisional) yang berkaitan dengan program pencegahan pasien jatuh yang ditujukan pada perawat sehinggai perawat dapat menerapkan program yang sesuai standar pedoman yang berlaku dirumah sakit tersebut.

Berdasarkan hasil penelitian ini, kepala ruangan memegang peranan penting dalam meningkatkan Self-efficacy staf perawat dalam memotivasi untuk mencapai tujuan organisasi khususnya mencegah pasien jatuh. Dukungan dapat meningkatkan self-efficacy pada individu termasuk perawat pelaksana (Lunenburg, 2011; Merluzzi et al., 2011). Selain hal tersebut, lingkungan disekitar individu termasuk perawat pelaksana juga dapat berpengaruh terhadap self-efficacy individu (Welsh, 2014). Faktor yang dapat memengaruhi self-efficacy yaitu persuasi sosial (social persuation) yang merupakan informasi tentang kemampuan yang disampaikan secara verbal oleh seseorang yang berpengaruh biasanya digunakan untuk meyakinkan seseorang bahwa dirinya cukup mampu melakukan suatu tugas. Peran interpersonal dan informasional kepala ruangan dapat memengaruhi self-efficacy 
perawat dalam pelaksanaan tugas perawat untuk mencegah pasien jatuh khususnya. Sehingga hubungan peran kepala ruangan dengan self-efficacy didapatkan hasil yang signifikan.

Temuan peneliti mengenai adanya hubungan signifikan antara peran kepala ruangan dengan self-efficacy perawat pelaksana dalam melakukan pencegahan jatuh tentu dapat pula berdampaki signfikan pada kinerja keperawatan di instalasi rawat inap. Hal tersebut didukung oleh beberapa penelitian yang menyatakan bahwa self-efficacy merupakan hal yang mengakibatkan peningkatan yang signifikan pada kemauan atau keinginan perawat untuk memberikan kinerja yang baik (Chairina \& Sularso, 2015; Setyawan, 2016). Selain itu, Jeeza, Hongkrailert, dan Sillabutra (2015) menyatakan bahwa self-efficacy dapat meningkatkan optimisme dan komitmen perawata untuk melakukan tindakan keperawatan.

\section{SIMPULAN DAN SARAN Simpulan}

Penelitian ini menemukan adanya hubungan yang signifikan dengan arah koefisien korelasi positif dan kekuatan hubungan sedang antara peran kepala ruangan dengan self-efficacy perawat dalam pencegahan pasien jatuh.

\section{Saran}

Disarankan untuk melakukan kajian lanjutan mengenai self-efficacy perawat pelaksana secara umum sehingga dapat dijadikan upaya dalam meningkatkan mutu dan kualitas RS terkait. Selain itu, peneliti selanjutnya diharapkan dapat melakukan penelitian mengenai self-efficacy perawat pelaksana dengan populasi yang lebih besar sehingga saat mengeneralisir hasil penelitian dan disarakan meneliti faktor-faktor lain yang belum diteliti dalam penelitian ini.

\section{DAFTAR PUSTAKA}

Bandura, A. (2008). Toward an agentic theeory of the self. Greenwich: Information Age Publishing.

Bastable, AS. B. (2017). Nursed as educator: Principle of teaching anda learning for nursing practice. Jones \& Bartlett Learning.

Cahyono, A. ((2015). Hubungan karakteristik dan tingkat pengetahuan Perawat terhadap pengelolaan keselamatan Pasien di rumah sakit. Jurnal Ilmiah WIDYA, 1)1).

Chairina, R. L., \& Sularso, R. A. (2015). Pengaruh kepemimpinan trasformasional terhadapp social competence, self efficacy dan kinerja perawat pada rumah sakit dr. Soebandi Jember. Jurnala Ikatan Sarjana Ekonomi Indonesia, 5(1), 19-28. ISSN: 2089-1482

Chanifah. (2013). Hubungan peran kepala ruang terhadap motivasi kerja perawatt di RS. A Jakarta. Jurnal FIK UI.

Gillies, D.A., (1994). Manajemen keperawatana: Suatu pendekatan sistem 2nd ed. Terjemahan, ed., Philadelphia: W.B. Saunders Company.

Isomi M. Miake-Lye., BA., Susanne Hempel, PhD.as Davids A. Ganz, MD, PhD., \& Paul G. Shekelle, MD, PhD (2013). Inpatient Fall Prevention Programs as as Patient Safety Strategy. A Systematic Review. Annalss of Interbala Medicine. Vol 158. No 5. doi: $\quad 1210.7326 / 0003-4819-158-5-$ 201303051-00005

Jeezaa, H., Hongkrailert, N., \& Sillabutra J. (2015). Effect of efficacy on nursing performance in indira gandhi memorial hospital, maldives. Journal of Public Health and Development, 13(2), 33-44. ISSN: 1905-1387

Katz, R. L. (1955). Skills off an effective administrator. Harvard Business Review, 33((1)). DOI: 10.1111/j.15406261.1955.tb01296.

Lee, K. H., \& Song, J. S. (2010). The effect of emotional intelligence ona selfefficacy anda job stress of nursesmediating role of self-efficacy. Journal of Korean Academy of Nursing 
Administration, $\quad 16(1), \quad 17-25$. Doi:10.11111/jkanaz.2010.16.1.17

Leverenz, M. D., \& Lape, J.A (2018). Education onn Fall Prevention to Improve Self-Efficacy of Nursing Staff in Long Term Care: aA Pilot Study. Internet Journal of Allied Health Sciences and Practice, 16(3), 6. Diunduh dari https://nsuworks.nova.edu/ijahsp/vol16 /iss3/6/

Lunenburg, F. C. (2011). Self-efficacy in the workplace: Implications for motivation and aperformance. Internationala Journal of Management, Business, and Administration, 14(1), 1-6. ISSN :2278-3660

Marquis, B. L., \& Huston, C. J. (2014). Leadership roles and management functions in nursing: Theory and application (8th ed.). New York: Lippincott williams \& Wilkins.

Merluzzi, AT. V., Philipp, E. J., Vachon, D. O., \& Heitzmann, C. A. (2011). Assessmento of self-efficacy for caregiving: The critical role of selfcare in caregiver stress and burden. Palliative and Supportive Care, 9(01), 115-24.

https://doi.org/10.1017/S14789515100 005070111111

Miri, S. A., Naha, N., Mansor, A., Alkali, A., \& Chikaji, A. (2015). The Role of First Line Nurse Manager, 6(4), a31-41.

Mom, T. JJ., Fourné, S. P., \& Jansen, J. J. (2015). Managers' work experienced, dexterity, and performance: The contingency role of the work context. Human Resource Management, 54(S1), qw133-s153.

Robbins, S. \& Judge T. (2015). Organisations behaviors. (4th Ed). New jersey: Upper Saddle Rivers

Setyawan, N. F. B. (2016). Hubungan antara harga diri dengann kinerja pada perawat rumah sakit pku muhammadiyah yogyakarta. Jurnal
Sosiology Humaniora, 6(1), 34-54. ISSN : 2087-1899

The Joint Commission. (2017). National Patient Safety Goalsi Effective January 2017. Nursinga Care Center Accreditation Program.

Thoha, M. (2015). Kepemimpinan dalam manajemen. Jakarta: CCV. Rajawali vol 28, suplemen No. 1 .

Triana, I.K.D.L., Yanti, N.P.E.D., \& Sulistiowati, N. M. D. (2017). Determinant of associate nurses' selfefficacy in treatment room installation of Hospital in Bali, Indonesia. Proceeding $2^{\text {nd }}$ Udayana International Nursing Conference. University of Udayana. Bali

Wahyuni, S.A (2007). analisis kompetensi kepala ruang dalam pelaksanaan standar manajemena pelayanann keperawatan dan pengaruhnya terhadap kinerja perawat dalam mengimplementasikan model praktik keperawatan profesional di Instalasi Rawat Inap RSUD Banjarnegara. Diunduh dari: http://eprints.undip.ac.id/18327/1/SRI_ WAHYUNI.pdf

Warshawsky, N. E., Havens, D. S., \& Knafl, G. (2012). The influence of interpersonal relationships on nursee managers' work engagement and proactive work behavior. The Journal of nursinga administration, 42(9), 418.doi:10.1097/NNA.0b013e3182668 12909090

Yetti, K., \& Novieastari, E. (2018). Hubungan perana kepala ruang terhadap perilaku perawat pelaksana dalam pelaksanaan keselamatan pasien. Jamc idea's, 4(1). Diunduh dari:

https://scholar.ui.ac.id/en/publications/ hubungan-peran-kepala-ruangterhadap-perilakuaperawat-pelaksana 